Ruth Breeze, Maurizio Gotti \& Carmen Sancho Guinda

(eds)

\title{
Interpersonality in Legal Genres
}

PETER LANG

Bern ........ 


\section{Contents}

CARMEN SANCHO GUINDA / MAURIZIO GOTTI / RUTH BREEZE

Framing Interpersonality in Law Contexts 9

Interactions among Legal Experts

DAVIDE MAZZI

"The words are plain and clear...": On Interpersonal Positioning in the Discourse of Judicial Interpretation.

TARJA SALMI-TOLONEN

Interpersonality and Fundamental Rights.

MARÍA ÁNGELES ORTS LLOPIS

Contractual Commitment or Obligation?

The Linguistic Interactions in Charter Parties

MiCHELE SALA

Interpersonal and Interactional Markers in Legal Research

Articles.

CHRISTOPH A. HAFNER

Stance in a Professional Legal Genre:

The Barrister's Opinion 
Interactions between legal experts and mixed audiences

VIJAY K. BHATIA

Interpersonal Constraints in Statutory Writing

CARMEN SANCHO GUINDA

Engagement in NTSB Decisions on Aviation Case Appeals

CHRISTOPHER WILLIAMS

Interpersonality in Legislative Drafting Guides and Manuals:

the Case of the Scottish Government Publication

Plain Language and Legislation

IGNACIO VÁZQUEZ-ORTA

Exploring the Interplay Between Discursive and Professional

Practices in Domain Name Arbitration Awards

ISMAEL ARINAS PELLÓN

Interpersonal Patent Relations: Persuasion Pointers to Novelty,

Creativity, and Ownership in U.S. Patent Property Claiming .255

Interactions between legal experts and lay people

\section{RUTH BREEZE}

The Discursive Construction of Professional Relationships through the Legal Letter of Advice

MAURIZIO GOTTI

Interpersonality in Mediation Discourse 
PATRIZIA ANESA

The Realization of Interpersonality Features in Jury Instructions ...329

ISABEL CORONA

The Management of Conflict: Arbitration in Corporate E-releases.. 355

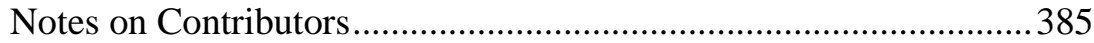

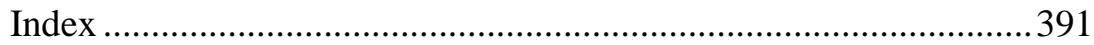


Interactions among Legal Experts 
Interactions between legal experts and mixed audiences 
Interactions between legal experts and lay people 